\title{
Production of some Colored Potato Genotypes in Organic Culture
}

\author{
Rodica SOARE ${ }^{1}$, Maria DINU ${ }^{2 *}$, Cristina BABEANU ${ }^{3}$, Mihnea MODRAN ${ }^{1}$ \\ ${ }^{1}$ Faculty of Agronomy, University of Craiova, 19 Libertatii St., 200583, Romania \\ ${ }^{2}$ Faculty of Horticulture,University of Craiova, 13 A.I. Cuza St., Romania \\ ${ }^{3}$ Faculty of Mathematics and Natural Sciences, University of Craiova, 13 A.I. Cuza St., Romania \\ *corresponding author: dinumariana@hotmail.com
}

Bulletin UASVM Horticulture 75(1) / 2018

Print ISSN 1843-5262, Electronic ISSN 1843-536X

DOI:10.15835/buasvmcn-hort: 003617

\begin{abstract}
The purpose of this study was to identify the cultivars of potatoes with good production capacity and high nutritional value under ecologically culture conditions. The biological material consisted of five new potatoes cultivars: Brasovean, Carpatin, Cranberry Red, Montain Rose, Purple Majesty and Blue Congo. These new, highly pigmented varieties have yellow, pink or red peel and pulp, due to its high anthocyanin content. In order to achieve the objective, the productivity elements were determined: number of tubers and medium weight/plant, productivity as well as starches, carbohydrates, vitamin C content and antioxidant capacity. The obtained results were statistically interpreted by the analysis of variance, and the differences between genotypes were estimated by the threshold of significance at $p \leq 0.05 \%$. Cultivar Carpatin recorded the best production ( $32.7 \mathrm{t} / \mathrm{ha}$ ) and Cranberry red and Montain Rose cultivars recorded the highest content in vitamin C (17.6 respectively $18.64 \mathrm{mg} / 100 \mathrm{~g}$ f.m) and Blue Congo with highest antioxidant capacity (162.65 DPPH $\mu \mathrm{MTE} / 100 \mathrm{~g}$ ).
\end{abstract}

Keywords: antioxidant capacity, ecological, quantitative

\section{Introduction}

Potato culture occupies an important place among crop plants because it is a source of human food, a good animal feed and raw material for industrial processing.

Coloured potatoes (Solanum tuberosum L.) are an important source of foods rich in antioxidant phenols. These antioxidants have effects against free radicals and lower the risk of coronary heart disease, by reducing cholesterol in the blood serum and by increasing the resistance of vascular walls (Chellaram et al., 2014).

Through breeding, new varieties have been created, with high production capacity, disease and pest resistance, and high quality attributes to meet market requirements. In recent years, new potato genotypes have emerged, which differ especially in the color of the peel and pulp.
Due to its pleasant taste, digestibility and high nutritional value, potatoes are increasingly used in human food, which are consumed in various forms (cooked, baked, fried, in the form of soups, salads, purees). Also, the potato has high energy value due to the high content of starch, proteins, fats, minerals and vitamins (Hoza et al., 2015). Consumption requires special attention because the tubers accumulate alkaloids that form solanine and at concentrations higher than $20 \mathrm{mg} / 100 \mathrm{~g}$ s.p. is toxic, carcinogenic (Soare and Duţă, 2011).

From an agrofitotechnical point of view, potato is a plant that harnesses mild, sandy-clay soil (even sandy at potatoes for early consumption) in more humid and cool areas, where cereals fail in culture.

Potatoes with colorful pulp are grown on all continents, but on small surfaces. For a long time, they have not shown interest to consumers 
because of the less attractive pulp color (Pazderů et al., 2015). Solanum tuberosum L. var. Vitelotte is a widely used potato variety for human consumption. Pigments responsible for attractive color belong to the anthocyanin class (Bontempo et al., 2013). At present, has grown the interest in these varieties, as healthy foods (Lange et al., 2007, Hecht, et al., 2015). In this respect, it was studied the behavior of a new potato assortment, which is distinguished by the color of the shells and pulp: yellow, cream, pink, purple, regarding the quantity and quality of the production.

\section{Material and methods}

The study was conducted in 2016 on an early potato organic crop in south-west Romania on a soil with clay-sandy texture $\left(44^{\circ} 19^{\prime} \mathrm{N}\right.$ and $\left.23^{\circ} 48^{\prime} \mathrm{E}\right)$, favorable area for growing potato. The experiment was placed in a completely randomized design with 3 repetitions. The planting was carried out in the second decade of March, after the following $70 \times 30 \mathrm{~cm}$ technological scheme. The biological material consisted of two autochthonous cultivars: Carpatian and Brasovean and four foreign cultivars: Cranberry Red, Montain Rose, Purple Majesty and Blue Congo.

At the preparation of the land, was applied $10 \mathrm{t} /$ ha of compost consisting of $50 \%$ of swine dumplings, $25 \%$ of ground mass and $25 \%$ of dry mass (dried leaves, straw and corn stalks). At planting, wood ash was sprinkled on the gutters at a dose of $500 \mathrm{~kg} / \mathrm{ha}$. Ash is both a natural repellent and an insecticide. Also at plantation, organic fertilizers, Guanito and Itallpolina $(500 \mathrm{~kg} / \mathrm{ha})$ were added. Guanito (6N-15P205+3K20) is a result of lilac excrements compost and Italpollina (4N-4P205-4K2O) is obtained by composting avian manure.

Prior to planting, the tubers were treated with Shore, $500 \mathrm{ml} / 100 \mathrm{l}$ water, ecologically produced for viruses, and after emergence 3 treatments were applied. Against pests were planted species with repellent effect: basil and marigolds and crop protection with agro-textil.

\section{Chemical analysis:}

The dry matter content was determined in the oven at $105{ }^{\circ} \mathrm{C}$ for 3 hours.

Reducing sugars (\%) were extracted in distilled water $(1: 50 \mathrm{w} / \mathrm{v})$ and assayed colorimetric with 3.5 dinitrosalicylic.
The vitamin $\mathrm{C}$ was determined by iodometric method, and reducing sugars (\%) by colorimetric method using 3.5 dinitrosalicylic acid (DNS).

Starch was determined from the potatos as described by Vasanthan (2001).

DPPH (2,2-diphenyl-1-picrylhydrazyl) radical scavenging assay: The capacity of sample extracts to reduce the radical 2,2-diphenyl-1picrylhydrazyl was assessed using the method of [13] with some modification. A $0.075 \mathrm{mM}$ (final concentration) DPPH solution in methanol was mixed with sample extracts and vortexed thoroughly. The absorbance of the mixtures at ambient temperature was recorded for $20 \mathrm{~min}$ at 2 min intervals. The absorbance of the remaining DPPH radicals was measured at $519 \mathrm{~nm}$. The normal color of DPPH will turn into yellow when its singlet electron is paired with a hydrogen atom coming from a potential antioxidant. A blank reagent was used to study stability of DPPH over the test time.

The scavenging activity of extracts was evaluated as a percentage of DPPH discoloration using the formula:

$$
\begin{aligned}
& \% \text { scavenging }=100 * \frac{\mathrm{A} 0-(\mathrm{A} 1-\mathrm{AS})}{\mathrm{A} 0} \\
& \% \text { scavenging }=100 * \frac{\mathrm{A} 0-(\mathrm{A} 1-\mathrm{AS})}{\mathrm{A} 0}
\end{aligned}
$$

where $\mathrm{A} 0$ is the absorbance of $\mathrm{DPPH}$ alone, A1 is the absorbance of DPPH + extract and AS is the absorbance of the extract only.

The Trolox calibration curve was plotted as a function of the percentage of DPPH radical scavenging activity. The final results were expressed as micromoles of Trolox equivalents, $\mathrm{TE} / 100 \mathrm{~g}(\mu \mathrm{mol} \mathrm{TE} / 100 \mathrm{~g} \mathrm{fw})$. All determinations were performed in triplicate, and all results were calculated as mean.

Statistics: The analysis of variance was performed on data for differences between and within the varieties using the ANOVA. Mean separations were determined by least significant difference (LSD) at $\mathrm{p} \leq 0.05 \%$.

\section{Results and discussions}

The data presented in Table 1 indicate that the varieties studied differ in phenotypic aspects: they have yellow peel and pulp, blue peel and pulp, pink peel and pulp, red peel and pulp or partially 
Table 1. Morphological characterization of potato cultivars

\begin{tabular}{cccccc}
\hline \multirow{2}{*}{ Cultivar } & \multirow{2}{*}{$\begin{array}{c}\text { The shape of } \\
\text { the tuber }\end{array}$} & \multicolumn{2}{c}{ Color } & \multirow{2}{*}{ Maturity } & The depth of the eyes \\
\cline { 3 - 4 } Brasovean & long oval & red & yellow & early & superficial - medium \\
\hline Carpatin & long oval & red & yellow & early & superficial - medium \\
\hline Blue Congo & oval elongated & pink & violet & early & superficial \\
\hline Purple Majesty & oval & blue & blue violet & early & medium \\
\hline Montain Rose & long oval & dark-purple & red & mid-early & superficial \\
\hline Crambery Red & oval & red & red & mid-early & superficial \\
\hline
\end{tabular}

Table 2. Morphological and production characteristics of studied potato cultivars

\begin{tabular}{ccccc}
\hline Cultivar & $\begin{array}{c}\text { Number of } \\
\text { stems/plant }\end{array}$ & $\begin{array}{c}\text { No. of } \\
\text { tubers/plant }\end{array}$ & $\begin{array}{c}\text { Weight of } \\
\text { tubers/plant } \\
\text { (g) }\end{array}$ & $\begin{array}{c}\text { Production } \\
\text { (t/ha) }\end{array}$ \\
\hline Braşovean & $5.0 \pm 0.5$ & $5.38 \pm 0.12 \mathrm{~b}$ & $510 \pm 70 \mathrm{a}$ & $30.6 \pm 1.9 \mathrm{a}$ \\
\hline Carpatin & $4.5 \pm 1.7$ & $5.81 \pm 0.06 \mathrm{~b}$ & $545 \pm 45 \mathrm{a}$ & $32.7 \pm 1.8 \mathrm{a}$ \\
\hline Blue Congo & $4,7 \pm 0.2$ & $5.50 \pm 0.8 \mathrm{~b}$ & $300 \pm 25 \mathrm{~b}$ & $18.0 \pm 1.5 \mathrm{bc}$ \\
\hline Purple Majesty & $3.5 \pm 1.1$ & $4.22 \pm 0.53 \mathrm{c}$ & $250 \pm 20 \mathrm{bc}$ & $15.0 \pm 0.8 \mathrm{c}$ \\
\hline Montain Rose & $3.7 \pm 0.3$ & $4.72 \pm 0.12 \mathrm{bc}$ & $320 \pm 10 \mathrm{~b}$ & $19.2 \pm 1.3 \mathrm{~b}$ \\
\hline Crambery Red & $4.9 \pm 0.3$ & $7.54 \pm 0.11 \mathrm{a}$ & $226 \pm 34 \mathrm{c}$ & $13.56 \pm 0.4 \mathrm{c}$ \\
\hline LSD 0.05\% & 2.45 & 1.12 & 76.19 & 3.92 \\
\hline
\end{tabular}

Note: Values represent the mean and SE,

Values in the same column followed by different superscript letters are significantly different at $\mathrm{p}<0.05$

violet peel and pulp due to the high content of anthocyanins.

The harvest of potatoes took place on 24.06.2016, determining some morphological characteristics and average weight/nest in each variety and variants. Regarding the medium no. of stems/plant, this was according to the data in the literature, from 3.5 to 5.5, and results reported by Masarirambi et al., 2012. Referring to the number of tubers this ranged from 4.22 to 5.81. The average weight of tubers/plant recorded the highest values in Romanian cultivars, Carpatin with $545 \mathrm{~g} /$ plant, respectively Brasovean with $510 \mathrm{~g} /$ plant. Foreign cultivars ranged between 250-320 g/plant (Tab. 2). Similar results were obtained on unpolluted soil (320g/plant) (Draghici et al., 2016).

The potato production of the studied cultivars showed high variability, from $13.56 \mathrm{t}$ /ha to 32.7 t/ha, evidencing the Carpatin autochthonous cultivar.

The biochemical composition of tubers depends mainly on the genetic structure, the environmental factors during the growing of the tubers, the variety, the storage conditions, etc.

The dry substance content of potato tubers is an important quality index in determining the processing capacity (Jariene et al., 2015). Potato cultivars with over $20 \%$ dried substance are suitable for industrial processing, chips and other dehydrated products (Rahman et al., 2016). Freshly harvested potatoes contain about 75\% water and 25\% dry matter (Addisu et al., 2014).

In the present study, the highest content in dry matter was obtained for Montain Rose $23.82 \%$ and Purple Majesty, with 23,81\%, and the lowest values was at Crambery Red cultivar, with $16.29 \%$ (Tab. 3). Other authors reported that the 
Table 3. Biochemical content and antioxidant activity in potato cultivars studied

\begin{tabular}{cccccc}
\hline Cultivar & $\begin{array}{c}\text { Dry } \\
\text { substance } \\
(\%)\end{array}$ & Starch $(\%)$ & $\begin{array}{c}\text { Reducing sugars } \\
(\%)\end{array}$ & $\begin{array}{c}\text { C Vitamin } \\
(\mathrm{mg} / 100 \mathrm{~g})\end{array}$ & $\begin{array}{c}\text { Antioxidant } \\
\text { activity } \\
\text { DPPH } \\
(\mu \mathrm{MTE} / 100 \mathrm{~g})\end{array}$ \\
\hline Braşovean & $19.47 \pm 0.07 \mathrm{c}$ & $13.71 \pm 0.71 \mathrm{c}$ & $0.419 \pm 0.03 \mathrm{~b}$ & $13.97 \pm 0.14 \mathrm{~d}$ & $85.39 \pm 0.72 \mathrm{~d}$ \\
\hline Carpatin & $21.92 \pm 0.36 \mathrm{~b}$ & $12.81 \pm 0.51 \mathrm{c}$ & $0.339 \pm 0.06 \mathrm{c}$ & $11.91 \pm 0.26 \mathrm{e}$ & $64.31 \pm 0.71 \mathrm{e}$ \\
\hline Blue Congo & $22.05 \pm 0.22 \mathrm{~b}$ & $16.94 \pm 0.86 \mathrm{~b}$ & $0.521 \pm 0.023 \mathrm{a}$ & $14.32 \pm 0.18 \mathrm{~d}$ & $162.65 \pm 1.48 \mathrm{a}$ \\
\hline Purple Majesty & $23.81 \pm 0.10 \mathrm{a}$ & $19.66 \pm 1.34 \mathrm{a}$ & $0.309 \pm 0.006 \mathrm{c}$ & $15.9 \pm 0.18 \mathrm{c}$ & $147.71 \pm 2.79 \mathrm{~b}$ \\
\hline Montain Rose & $23.82 \pm 0.18 \mathrm{a}$ & $16.99 \pm 0.51 \mathrm{~b}$ & $0.174 \pm 0.006 \mathrm{~d}$ & $18.64 \pm 0.39 \mathrm{a}$ & $149.66 \pm 1.54 \mathrm{~b}$ \\
\hline Crambery Red & $16.29 \pm 0.73 \mathrm{~d}$ & $14.25 \pm 0.25 \mathrm{c}$ & $0.338 \pm 0.01 \mathrm{c}$ & $17.6 \pm 0.48 \mathrm{~b}$ & $97.07 \pm 0.93 \mathrm{c}$ \\
\hline LSD 0.05\% & 0.98 & 2.18 & 0.061 & 0.83 & 4.33 \\
\hline
\end{tabular}

Note: Values represent the mean and SE.

Values in the same column followed by different superscript letters are significantly different at $\mathrm{p}<0.05$

content in dry matter ranged from 13.56 to 24.60 \% (Rahman et al., 2016; Jariene et al., 2015), in a study regarding the biochemical composition at colored potatoes reported values from 20.63 at Blue Congo and $26.71 \%$ at Viollete.

Concerning the starch content at the cultivars studied, it ranged from $12.81 \%$ to $19.66 \%$. Regarding reductive carbohydrates, there was a variation amplitude between $0.174 \%$ for Montain Rose and $0.521 \%$ for Blue Congo.

Considerable differences were found in Vitamin $\mathrm{C}$ in the cultivars studied. Thus, the potatoes with colored pulp had higher than values in yellow pulp potatoes. The highest content was recorded in the Montain Rose $18.64 \mathrm{mg} / 100 \mathrm{~g}$, with red pulp. The results obtained in this study are consistent with those presented by Silveira $e t$ al. (2011).

Pigments present in colored potatoes are powerful antioxidants in human diet (Brown, 2005). Anthocyanins content and potato antioxidant activity depending on the maturity, variety, environmental conditions. pulp color. High temperature preparation destroys anthocyanin compounds and significantly lowers potato color (Chellaram et al., 2014).

Regarding the antioxidant activity (DPPH) of potato cultivars. in the present study the highest values were recorded in three of the colored cultivars from $147.71 \mu \mathrm{MTE} / 100 \mathrm{~g}$ to 162.65 $\mu \mathrm{MTE} / 100 \mathrm{~g}$. while the indigenous cultivars recorded values much lower than foreign ones, from $64.31 \mu \mathrm{MTE} / 100 \mathrm{~g}$ at Carpatin to 85.39 $\mu \mathrm{MTE} / 100 \mathrm{~g}$ at Brasovean. So, it's obvious that in the case of colored pulp genotypes. the values significantly outnumber those with yellow or white pulp. Similar results have been reported in a study of six genotypes of colored pulp (red or purple), white or yellow, the antioxidant activity was significantly higher in varieties with purple colored than in white and yellow pulp (Sang et al., 2016). They found that the highest activity to capture ABTS radicals in violet varieties was $121.39 \mathrm{mg} / 100 \mathrm{~g}$ AAE dried samples, while the yellow and white genotypes had the smallest ABTS activities to capture radical of 80.64 and $71.88 \mathrm{mg}$ AAE/100 g, respectively.

Also, in another study of 13 potato cultivars with different pulp color, the high levels of anthocyanic pigments that print high antioxidant activity in colored cultivars were recorded (Pazderů et al., 2015). Chellaram et al. (2014), in a study to measure the antioxidant capacity of three violet potato cultivars processed differently, suggests that for the efficient use of purple potato dye they must be kept away from light and heat treatment.

\section{Conclusion}

The evaluated potato cultivars are of great interest. given their high content of bioactive compounds and antioxidant activity. Comparing the cultivars studied with regard to the obtained production, it is found that the Brasovean and Carpatin Romanian cultivars recorded the best yields compared to the varieties with colored pulp. 
From the nutritional point of view, Cranberry red and Montain Rose cultivars with colored pulp, recorded the highest content in vitamin $\mathrm{C}$ (17.6 and respectively $18.64 \mathrm{mg} / 100 \mathrm{~g} \mathrm{fm}$ ) and the highest antioxidant capacity was at Blue Congo (162.65 DPPH $\mu$ MTE/100g). These cultivars are recommended in the ecological farming system.

\section{References}

1. Addisu S, Chemeda, Bultosa G, Dechassa N (2014). Effect of Variety and Storage on the Tuber Quality of Potatoes Cultivated in the Eastern Highlands of Ethiopia. Science. Technology and Arts Research Journal Sci. Technol. Arts Res. J., 3(1): 84-89.

2. Albert IO (2010). Research on organic potato cultivation. Agricultura. IXX. 1. 2: 73-74.

3. Bontempo P. Carafaa V, Grassib R, Basilec A, Tenored GC, Formisanoe C, Riganoe D, Altucci L (2013). Antioxidant. antimicrobial and anti-proliferative activities of Solanum tuberosum L. var. Vitelotte. Food Chem Toxicol., 55: 30412.

4. Brown CR (2005). Antioxidants in Potato. American Journal of Potato Research 82: 163-172.

5. Chellarama C, Parthasarathyb V, Praveena MM, Johna AA, Ananda TP, Priyac DK (2014). Analysis of Phenolic Content and Antioxidant Capacity of Potato. Solanum tuberosum L from Tamilnadu Region. India. APCBEE Procedia 8: 105108.

6. Draghici EM, Scarlat V, Pele M, Postamentel M, Somacescu C (2016). Usage of Perlite in Polluted Sandy Soils for Potato Crop. Revista de chimie. vol. 67(11): 2281-2286.

7. Hecht K (2015). Editorial healthy snacks: Recent trends and innovative developments to meet current needs. LWT - Food Science and Technology, 62: 373-375.
8. Hejtmánková K, Piv V, Trnková E, Hamouz K, Lachman J (2009). Quality of Coloured Varieties of Potatoes. Czech J. Food Sci. Vol. 27: 310-313.

9. Hoza G, Enescu BG, Becherescu A (2015). Research regarding the effect of applying herbicides to combat weeds in quickly-potato cultures. Scientific Papers. Series B. Horticulture. Vol. LIX: 219-224.

10. Lange MC, Lemay DG, German JB (2007): A multi-ontology framework to guide agriculture and food towards diet and health. Journal of the Science of Food and Agriculture. 87: 1427-1434.

11. Masarirambi MT, Mandisodza FC, Mashingaidze AB, Bhebhe E (2012). Influence of plant population and seed tuber size on growth and yield components of potato (Solanum tuberosum). Int. J. Agric. Biol. 14: 545-549.

12. Rahman MA, Tuhin SR, Chowdhury IF, Haque N, Afroj M, Ahmed S (2016). Biochemical composition of different potato varieties for processing industry in Bangladesh. Agriculture-Science and Practice, 1-2: 81-89.

13. Pazderů K, Hamouz K, Lachman J, Kasal P (2015). Yield potential and antioxidant activity of potatoeswith coloured flesh. Plant Soil Environ, 61(9): 417-421.

14. Sang HL, Seung HO, Hwang IG, Hyun YK, Woo KS. Woo KH, Hong SK, Lee J, Heon SJ (2016). Antioxidant Contents and Antioxidant Activities of White and Colored Potatoes (Solanum tuberosum L.). Prev. Nutr. Food Sci., 21(2):110116.

15. Silveira LR, Chiesa VB, Tavares IB, Souza RC, De Silveira MA, Da Alves DC, Junior WP (2011). Physical-chemical characterization and clones of sweet potato of orange pulp in the conditions of PalmasTO. Estudos. 38(2): 365380.

16. Soare R, Duţă A (2011). Tehologii legumicole alternative. Ed. Universitaria, Craiova.

17. Vasanthan $\mathrm{T}$ (2001). Overview of laboratory isolation of starch from plant materials. Food Anal Chem. Unit E2.1.1-E2.1.6. 